\title{
WEB HOSTING
}

\author{
Agus Mochamad Nur \\ 185100009 \\ Fakultas Komputer \\ agusmochamad.student@umitra.ac.id
}

\begin{abstract}
Web hosting adalah layanan jasa atau penyewaan tempat untuk menyimpan file atau bentuk script yang berada Internet dan memungkinkan untuk perorangan atau pun organisasi guna menampilkan layanan jasa atau produk di web atau bahkan situs Internet seperti web portal, web pribadi dan banyak lagi.

Web hosting atau dapat juga diartikan sebagai tempat penyimpanan data berupa filedengan ukuran megabytes hingga ukuran besar yaitu terabytes yang memilikikoneksi ke internet sehingga data dalam web hosting tersebut dapat di re\$uest 有 di minta"atau di akses oleh pengguna internet dari semua penjuru atau global. \%al inilah yangmenyebabkan website dapat di akses secara bersamaan dalam dekade satu waktu.Pada dasarnyaser\&er web hosting menggunakan sebuah komputer biasa yang sudahkita kenal, namun komputer untuk web hosting menggunakan beberapa komponen dengan jumlah daya tamung luar biasa dan program dasar sebuah ser\&er hosting harus mampuuntuk online dalam waktu '( jam setiap hari dan tanpa harus dimatikan atau di refreshdalam jangka waktu cukup lebih lama daripada komputer biasa yang sudah kita kenal.Sekarang kita sedikit tahu tentang apa itu web hosting untuk sekarang ini banyak sekali layanan web hosting yang memungkinan anda untuk memilih dari berbagai tempat.misalnya di indonesia, singapore, amerika dan banyak lagi. pemilihan tempat ini sangat terpengaruh pada kecepatan akses ketika seseorang ingin mengunjungi website anda. untuk menentukan serta menangani pengguna sebaiknya anda memilih web hosting yang terdekatdengan anda. ini salah satu pilihan dan salah satu trik tentang seo.banyak yang menyarankan untuk memilih beberapa layanan web hosting. untuk itu tidak anda salahnya kalau anda baca halaman yang pernah saya kupas sebelumnya yaitu menentukan web hosting yang handal. demikian pengertian sebenarnya semoga artikel ini bermanfaat untuk anda untuk menentukan website anda dimana seharunya.
\end{abstract}

\section{A. PENDAHULUAN}

Web hosting merupakan penggabungan dari kata web dan hosting, dan apabiladiartikan satu persatu maka web merupakan sebuah halaman situs yang bisa diakses dengan menggunakan sebuah aplikasi browser, hosting merupakan sebuah tempat yang digunakan untuk menyimpan halaman + halaman web tersebut, dimana dalam penyimpanannya, 
halaman + halaman web akan diletakan dalam sebuah komputer web server yang terhubung ke internet dalam bentuk file + file data. server + server yang digunakan untuk menyimpan data web biasanya dikelola oleh sebuah perusahaan yang khusus menangani penyewaan web hosting. dan web hosting sendiri merupakan salah satu bentuk penerapan dari bisnis online yang sudah kita bahas sebelumnya. Perusahaan penyedia layanan webhosting biasanya disebut dengan webhost.Di Indonesia sendiri telah banyak sekali penyedia + penyedia layanan web hosting dengan berbagai keunggulan dan penawaran fitur + fitur yang berbeda antara satu dengan yang lain, dan yang membedakan antara perusahaan yang satu dengan yang lain adalah dari segi layanan seperti besarnya kapasitas ruang penyimpanan, konektifitas serta data transfer dalam penawaran paket + paket hosting yang mereka sediakan Macam - Macam Server hosting :

1. Share Hosting

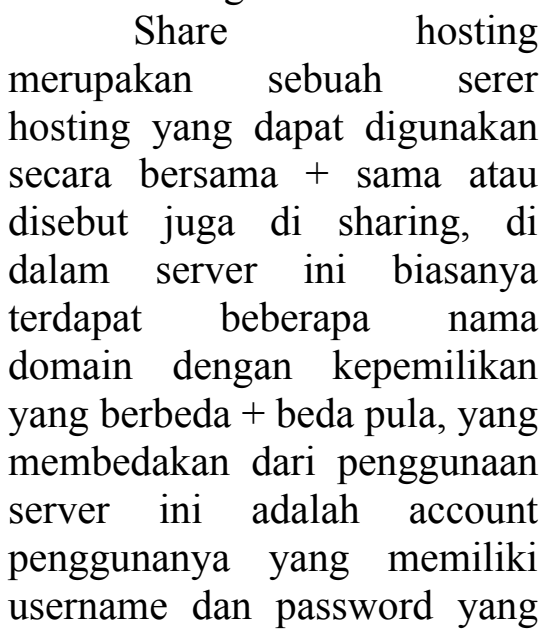

berbeda, biaya untuk menyewa server hosting ini sangatlah murah dibandingan dengan jenis server yang lainya, jadi untuk sobat yang masih pemula sangatlah cocok untuk menyewa server hosting yang satu ini.

2. Virtual Private Server biasanya disebut juga dengan nama virtual Dedicated Server yang merupakan sebuah server yang dibagi + bagi menjadi sebuah virtual mesin, jadi dalam satu komputer server terdapat beberapa sistem operasi ser\&er, tentunya secara kepemilikan antara sistem operasi satu dengan yang lainnya berbeda. untuk menyewa server hosting jenis ini lebih mahal dari pada sobat menyewa share hosting, tetapi dari segi kualitas layanan keleluasaan penggunaanya lebih baik dibandingkan dengan shere hosting.

\section{Dedicated Server}

Server yang satu ini biasanya digunakan untuk penyimpanan aplikasi yang lebih besar dari pada Share hosting maupun VPS, jadi pengguna menyewa secara keseluruhan dari komputer server yang disediakan oleh webhost. Keleluasaan dalam menggunakan komputer server ini lebih penuh, baik dari segi hardware maupun software.

4. Colocation Server 
Colocation Server merupakan sebuah server yang digunakan untuk keperluan web host, jadi apabila sobat komputer ingin memiliki usaha web hosting maka sobat dapat menyewa colocation Server untuk mendukung usaha sobat, tentunya harga yang ditawarkan oleh pihak provider lebih mahal dari jenis server yangs ebelum + sebelumnya

\section{в. PEMBAHASAN / STUDI KASUS}

Setiap orang ataupun perusahaan dapat menyewa tempat atau memanfaatkan jasa web hosting ini, didukung dengan kemajuan teknologi informasi yang ada saat ini maka pemanfaatan jasa web hosting merupakan sarana alternatif yang handal untuk Promosi,Menyebarkan Informasi, !erjualan, layanan Publik sampai dengan sekedar tempat untuk menumpahkan isi hati yang kelabu ke dalam buku harian berbasis web log web log.

Di Indonesia dengan sekitar 100 juta pengguna telepon genggam yang tentu saja dapat tersambung ke internet melalui gprs, tidak ada alasan lagi untuk tidak tersambung kedunia maya, bahkan di daerah terpencil sekalipun.

Seorang mahasiswa kedokteran, dengan dana yang terbatas, untuk mengantisipasi membeli buku kuliah kedokteran yang harganya bisa mencapai jutaan rupiah, dapat dengan mudah memperoleh informasi ilmu pengetahuan dan teknologi melalui situs web,dan ini menjadi tanggung jawab penyelenggara pendidikan untuk menyediakan layanan web site guna memajukan pendidikan. !ahkan seorang dosen sebaiknya memiliki website. Singkatnya, bila anda telah membuat prototip disain yang dapat dibaca oleh internet browser seperti html, maka sudah waktunya anda menaruh disain itu di internet dengan mengupload disain anda ke perusahaan yang melayani penjualan hosting.

kapan anda membutuhkan Situs web

Disaat anda ingin memasarkan produk atau jasa melewati batas kabupaten, propinsi, negara, samudra dan benua, disaat anda ingin orang lain memperoleh informasi yang benar mengenai hal+hal kemanusiaan, disaat anda ingin menyebarluaskan pengetahuan demi kesejahteraan sesama manusia, disaat anda ingin melakukan transaksi bisnis yang memudahkan pelangan anda menjangkaunya dari sebuah vila tempat peristirahatan dengan privasi yang tinggi, disaat itulah anda membutuhkan layanan web hosting.Situs web adalah sebuah channel above the line yang termurah yang ada di 
pasar saat ini, kemampuan broadcast jam seminggu, tak terbatas pada aspek demografis, geografis, menjadikannya positif dalam rasio cost to benefit. bila anda ingin ditemukan, dikenal, diapresiasi, mengiklankan diri produk anda, berarti andawajib memiliki situs web

Dimana menyewa web hosting Ada ratusan bahkan ribuan penyelenggara jasa web hosting, ada dapat memulainya dengan mencari dari mesin pencari google atau yahoo, beberapa penyedia jasa layanan web hosting di indonesia. jangan ragu untuk bertanya, bandingkan fitur kunci seperti kapasitas ruang dan kapasitas bandwidth, jangan tergiur oleh promosi penyelenggara jasa web hosting yang bombastis

\section{c. ID SECURITY QWTD4452377-ASP-5244166}

\section{KESIMPULAN}

Web hosting adalah layanan jasa atau penyewaan tempat untuk menyimpan file atau bentuk script yang berada Internet dan memungkinkan untuk perorangan atau pun organisasi guna menampilkan layanan jasa atau produk di web atau bahkan situs Internet seperti web portal, web pribadi dan banyak lagi.

Web hosting merupakan penggabungan dari kata web dan hosting, dan apabiladiartikan satu persatu maka web merupakan sebuah halaman situs yang bisa diakses dengan menggunakan sebuah aplikasi browser, hosting merupakan sebuah tempat yang digunakan untuk menyimpan halaman + halaman web tersebut, dimana dalam penyimpanannya, halaman + halaman web akan diletakan dalam sebuah komputer web server yang terhubung ke internet dalam bentuk file + file data. server + server yang digunakan untuk menyimpan data web biasanya dikelola oleh sebuah perusahaan yang khusus menangani penyewaan web hosting. dan web hosting sendiri merupakan salah satu bentuk penerapan dari bisnis online yang sudah kita bahas sebelumnya . Perusahaan penyedia layanan webhosting biasanya disebut dengan webhost.Di Indonesia sendiri telah banyak sekali penyedia + penyedia layanan web hosting dengan berbagai keunggulan dan penawaran fitur + fitur yang berbeda antara satu dengan yang lain, dan yang membedakan antara perusahaan yang satu dengan yang lain adalah dari segi layanan seperti besarnya

\section{E. DISKUSI}

Saya bersama teman saya
bernama maulidun nur
mendiskusikan tentang
Pengertian web hosting.
Jika ingin membuat website,
maka langkah paling pertama yang harus dilakukan adalah mencari perusahaan hosting yang menyediakan space server. Web host menyimpan semua file, aset, dan database pada server. Ketika seseorang mengetikkan nama domain ke

kolom address browser, host akan mentransfer semua file yang dibutuhkan untuk menyelesaikan request.

Pada dasarnya, cara kerja web hosting hampir sama ketika Anda hendak menyewa rumah. Anda harus membayar biaya sewa setiap bulan agar server bisa berfungsi penuh. 
Untuk meminimalkan risiko, setiap paket hosting di Hostinger menawarkan jaminan uang kembali dalam 30 hari sejak masa pembelian sehingga Anda bisa mencoba terlebih dulu layanannya, apakah sesuai kebutuhan atau tidak. Bahkan Anda juga bisa melirik paket single kami yang didesain secara khusus untuk web atau blog sederhana. Apabila nantinya website semakin berkembang dan traffic semakin ramai, maka Anda bisa melakukan upgrade ke paket hosting yang kapasitasnya lebih besar.

Jika ingin menggunakan layanan kami, Anda tidak perlu menguasai bahasa teknis pemrograman untuk mengelola situs. Akun hosting Hostinger telah dilengkapi antarmuka pengguna grafis sehingga Anda dapat mengelola setiap aspek yang ada di website Anda.

Sebagai contoh, Anda bisa upload HTML dan file lainnya ke server, install sistem manajemen konten seperti WordPress, mengakses database, dan membackup situs Anda.

Walaupun platform hosting cPanel banyak digunakan web host, bagi sebagian user yang minim pengetahuan teknis, penggunaan tool canggih ini sedikit memusingkan. Karena itulah, tim kami membuat control panel sendiri bagi para pengguna Hostinger. Control panel Hostinger memiliki user interface yang menarik dan intuitif serta mudah digunakan, bahkan bagi para pemula di dunia hosting. Hingga saat ini, control panel Hostinger sudah membantu klien kami dalam mengelola dan mengembangkan semua aspek di akun hosting tanpa hambatan.
Selain menyediakan server space untuk website, penyedia web hosting juga menawarkan layanan lain terkait manajemen website, seperti:

- Sertifikat SSL (untuk mengamankan situs dengan menggunakan protokol https://)

- Hosting email

- Page builder

- Tool developer

- Layanan bantuan pelanggan (bisa melalui live chat)

- Backup website yang otomatis

- One-click software install (misalnya, untuk WordPress atau Drupal)

\section{F. REFERENCE}

[1] O. M. Febriani and A. S. Putra, "Sistem Informasi Monitoring Inventori Barang Pada Balai Riset Standardisasi Industri Bandar Lampung," $J$. Inform., vol. 13, no. 1, pp. 9098, 2014.

[2] A. S. Putra, "Paperplain: Execution Fundamental Create Application With Borland Delphi 7.0 University Of Mitra Indonesia," 2018.

[3] A. S. Putra, "2018 Artikel Struktur Data, Audit Dan Jaringan Komputer," 2018.

[4] A. S. Putra, "ALIAS 
MANAGER USED IN
DATABASE
STUDI CASE DB DEMOS."

[5] A. S. Putra, "COMPREHENSIVE SET OF PROFESSIONAL FOR DISTRIBUTE COMPUTING."

[6] A. S. Putra, "DATA ORIENTED RECOGNITION IN BORLAND DELPHI 7.0."

[7] A. S. Putra, "EMBARCADERO DELPHI XE 2 IN GPU-POWERED FIREMONKEY APPLICATION."

[8] A. S. Putra, "HAK ATAS KEKAYAAN INTELEKTUAL DALAM DUNIA TEKNOLOGY BERBASIS REVOLUSI INDUSTRI 4.0."

[9] A. S. Putra, "IMPLEMENTASI

PERATURAN

PERUNDANGAN UU. NO 31

TAHUN 2000 TENTANG

DESAIN INDUSTRI

BERBASIS INFORMATION TECHNOLOGY."

$\begin{array}{lr}\text { A. S. } & \text { Putra, } \\ \text { "IMPLEMENTATION } & \text { OF } \\ \text { PARADOX DBASE." } & \end{array}$

[11] A. S. Putra, "IMPLEMENTATION OF TRADE SECRET CASE STUDY SAMSUNG MOBILE PHONE."

[12] A. S. Putra, "IMPLEMENTATION

PATENT FOR APPLICATION

WEB BASED CASE STUDI

WWW. PUBLIKLAMPUNG. COM."

[13] A. S. Putra, "IMPLEMENTATION
SYSTEM FIRST TO INVENT IN DIGITALLY INDUSTRY." [14] A. S. Putra, "MANUAL REPORT \& INTEGRATED DEVELOPMENT

ENVIRONMENT BORLAND DELPHI 7.0."

[15] A. S. Putra, "PATENT

AS RELEVAN SUPPORT RESEARCH."

[16] A. S. Putra, "PATENT

FOR RESEARCH STUDY CASE OF APPLE. Inc."

[17] A. S. Putra, "PATENT PROTECTION FOR APPLICATION INVENT."

[18] A. S. Putra, "QUICK REPORT IN PROPERTY PROGRAMMING."

[19] A. S. Putra, "REVIEW CIRCUIT LAYOUT COMPONENT

REQUIREMENT ON ASUS NOTEBOOK."

[20] A. S. Putra, "REVIEW TRADEMARK PATENT FOR INDUSTRIAL

TECHNOLOGY BASED 4.0."

[21] A. S. Putra, "TOOLBAR COMPONENT PALLETTE IN OBJECT ORIENTED

PROGRAMMING."

[22] A. S. Putra, "WORKING DIRECTORY SET FOR PARADOX 7."

[23] A. S. Putra, "ZQUERY CONNECTION

IMPLEMENTED

PROGRAMMING STUDI CASE PT. BANK BCA Tbk." [24] A. S. Putra, D. R. Aryanti, and I. Hartati, "Metode SAW (Simple Additive Weighting) sebagai 
Sistem Pendukung Keputusan

Guru Berprestasi (Studi Kasus: SMK Global Surya)," in Prosiding Seminar Nasional Darmajaya, 2018, vol. 1, no. 1, pp. 85-97.

[25] A. S. Putra and O. M. Febriani, "Knowledge Management Online Application in PDAM Lampung Province," in Prosiding International conference on Information Technology and Business (ICITB), 2018, pp. 181-187. [26] A. S. Putra, O. M. Febriani, and B. Bachry, "Implementasi Genetic Fuzzy System Untuk Mengidentifikasi Hasil Curian Kendaraan Bermotor Di Polda Lampung," SIMADA (Jurnal Sist. Inf. dan Manaj. Basis Data), vol. 1, no. 1, pp. 21-30, 2018.

[27] A. S. Putra, H. Sukri, and K. Zuhri, "Sistem Monitoring Realtime Jaringan Irigasi Desa (JIDES) Dengan Konsep Jaringan Sensor Nirkabel," IJEIS (Indonesian J. Electron. Instrum. Syst., vol. 8, no. 2, pp. 221-232.

[28] D. P. Sari, O. M. Febriani, and A. S. Putra, "Perancangan Sistem Informasi SDM Berprestasi pada SD Global Surya," in Prosiding Seminar Nasional Darmajaya, 2018, vol. 1, no. 1, pp. 289294. 